\title{
Pengaruh Euthyroid Sick Syndrome pada Mortalitas Anak Sakit Kritis
}

Ony Sapto Pramana, Sri Martuti, Bambang Soebagyo

Bagian Ilmu Kesehatan Anak Fakultas Kedokteran Universitas Sebelas Maret, Surakarta

Latar belakang. Penelitian di Indonesia tentang pengaruh euthyroid sick syndrome (ESS) pada mortalitas anak memberikan hasil berbeda dan terbatas pada subjek anak dengan sepsis.

Tujuan. Menilai pengaruh ESS pada mortalitas dan faktor risiko mortalitas pada anak sakit kritis.

Metode. Penelitian kohort prospektif dilakukan pada bulan Mei hingga Juli 2016 di PICU dan HCU RS Dr. Moewardi Surakarta. Sampel 40 anak diambil secara konsekutif. Data dianalisis menggunakan statistik uji $\mathrm{x}^{2}$, uji t, dan regresi logistik dengan program SPSS 20.0.

Hasil. Terdapat 40 subjek, 21 anak laki-laki, 25 anak dengan penyakit non bedah dan 27 anak gizi baik. Kejadian ESS terdapat pada $27(67,5 \%)$ anak dan $8(29,6 \%)$ di antaranya meninggal. Faktor risiko yang berhubungan dengan mortalitas adalah skor PELOD $\geq 20$, sepsis dan penggunaan inotropik. Jenis kelamin, usia, status gizi, dan jenis penyakit tidak berhubungan dengan mortalitas. ESS tidak berpengaruh terhadap mortalitas ( $\mathrm{p}=0,120$; OR 5,05; IK95\%: 0,56-45,64). Hasil analisis multivariat menunjukkan skor PELOD $\geq 20$ merupakan faktor risiko utama mortalitas ( $p=0,042$; OR 14,48; IK95\%: 1,10-190,42). ESS tidak berpengaruh terhadap mortalitas ( $\mathrm{p}=0,120$; OR 5,05; IK95\%: 0,56-45,64).

Kesimpulan. Euthyroid sick syndrome tidak berpengaruh pada mortalitas anak sakit kritis, ESS terjadi pada $67,5 \%$ anak sakit kritis, dan skor PELOD $\geq 20$ merupakan faktor risiko utama mortalitas. Sari Pediatri 2017;18(6):453-8

Kata kunci: euthyroid sick syndrome, mortalitas, anak

\section{The Effect of Euthyroid Sick Syndrome on Mortality in Critically ill Children}

Ony Sapto Pramana, Sri Martuti, Bambang Soebagyo

Background. Research in Indonesia about the effect of ESS on mortality in critically ill children provide different results and are limited to the sepsis subject.

Objectives. To analyze the effect of ESS on mortality as well as the mortality risk factors in critically ill children.

Methods. Prospective cohort study was conducted between May and July 2016 at PICU and HCU Moewardi Hospital. Fourty children were enrolled consecutively. Data were analyzed with SPSS 20.0 statistical analizes used independent t test, and logistic regression.

Results. Of the 40 children, 21 were boys, 25 children with non-surgical type of disease and 27 chilren were not malnourished. ESS presented in $27(67.5 \%)$ children and 8 (29.6\%) of them passed away. The risk factors associated with mortality were: PELOD score $\geq 20$, sepsis and the use of inotropes. Gender, age, nutritional status and type of disease were not associated with mortality. ESS had no effect on mortality ( $\mathrm{p}=0.120$; OR 5.05; IK95\%0.56 to 45.64). Multivariate analysis showed PELOD score $\geq 20$ was a major risk factor of mortality ( $\mathrm{p}=0.042$; OR 14.48 ; IK95\% 1.10 to 190.42 ).

Conclusion. Euthyroid sick syndrome occurred in $67.5 \%$ of children. ESS had no effect on mortality in critically ill children. PELOD scores $\geq 20$ was a risk factor for mortality. Sari Pediatri 2017;18(6):453-8

Keywords: euthyroid sick syndrome, mortality, children

Alamat korespondensi: Dr. Ony Sapto Pramana. Bagian Ilmu Kesehatan Anak Fakultas Kedokteran Universitas Sebelas Maret, Surakarta. Email: ospramana.dr@gmail.com 
$\mathrm{P}$ enyakit kritis adalah suatu kondisi yang mengancam jiwa. Pasien tergantung pada dukungan medis yang intensif agar organ vital tetap berfungsi. ${ }^{1}$ Hormon tiroid berperan penting pada adaptasi fungsi metabolisme selama stres dan sakit kritis. Kondisi ini secara terminologi disebut euthyroid sick syndrome (ESS) atau non thyroidal illness (NTI), dengan karakteristik kadar triiodotironin (T3) dalam serum menurun, sedangkan tiroksin (T4) normal atau turun dan thyroid stimulating hormon (TSH) normal, turun, atau sedikit meningkat. ${ }^{2}$ Frekuensi kelainan fungsi tiroid berhubungan erat dengan beratnya penyakit. Menurut data di Amerika Serikat, ${ }^{4}$ kelainan yang sering terjadi adalah penurunan kadarT3, pada sekitar 40-100\% kasus ESS, yang sejajar dengan peningkatan reverse T3 (rT3). Kadar T4 akan menurun bila keparahan penyakit meningkat. Pasien yang dirawat dengan ESS, 10\% memiliki nilai TSH rendah. Mortalitas dan morbiditas ESS tergantung pada penyakit dasar, tingkat keparahan, dan durasi penyakit. Euthyroid sick syndrome dapat terjadi pada semua ras, jenis kelamin, dan usia. ${ }^{3}$ Kondisi ESS berhubungan dengan mortalitas, lama rawat, dan penggunaan ventilator. Penurunan kadar FT4 bersama FT3 dianggap sebagai proses maladaptif yang ditunjukkan dengan perburukan pasien. ${ }^{4}$

Penelitian di India tahun $2009^{5}$ menunjukkan bila kadar T3 dan T4 rendah maka risiko kematian akan meningkat 30 kali. Faktor usia, jenis kelamin, lama rawat, penggunaan ventilator dan dukungan inotropik pada penelitian tersebut tidak berkorelasi dengan profil tiroid pasien sakit kritis. Peneliti berkesimpulan bahwa skor PRISM pada 24 jam pertama dan kadar T4 adalah prediktor pasien untuk bertahan hidup. Penelitian di RS Kariadi Semarang ${ }^{6}$ menunjukkan tidak terdapat perbedaan kadar hormon tiroid pada pasien sepsis dengan luaran perbaikan ataupun perburukan. Sementara penelitian di RSCM Jakarta menunjukkan hormon tiroid menurun pada anak sepsis dengan mayoritas memiliki T3 yang rendah, sedangkan kadar TSH tidak berhubungan dengan skor PELOD dan luaran pasien. ${ }^{7}$ Penelitian ini bertujuan untuk menilai pengaruh ESS pada mortalitas anak sakit kritis yang dirawat di ruang rawat intensif.

\section{Metode}

Studi kohort prospektif dengan kriteria inklusi anak sakit kritis berusia 1 bulan sampai 18 tahun yang dirawat di PICU dan HCU anak, RSUD Dr. Moewardi, Surakarta antara bulan Mei hingga Juli 2016. Kriteria eksklusi adalah pasien dengan riwayat penyakit kelenjar tiroid. Subjek pada penelitian adalah 40 dengan rumus rules of thumb. Pengambilan sampel menggunakan metode konsekutif. Kadar TSH (uIU/ml), FT3 (pmol/l) dan FT4 (pmol/l) diukur dengan alat minividas dengan metode Enzyme Linked fluorescents Assay (ELFA) milik laboratorium Patologi Klinik RS Dr. Moewardi. Anak dibagi dalam kelompok ESS dan Non ESS. Variabel perancu penelitian ini adalah usia, status gizi, sepsis, penggunaan obat inotropik dan Skor PELOD (pediatric logistic organ dysfunction). Definisi ESS adalah pasien dengan kadar FT3 turun, FT4 dan TSH normal atau turun. Penelitian dilakukan atas persetujuan Komite Etik RS Dr. Moewardi dan orangtua dengan menandatangani informed consent. Pemeriksaan TSH, FT3, FT4 dilakukan pada 24 jam pertama dirawat. Data dianalisis dengan program SPSS 20.0 dengan uji $\mathrm{x}^{2}$, dan uji $\mathrm{t}$ independen. Pengaruh faktor risiko terhadap mortalitas dianalisis secara univariat, bila hasil bermakna dilanjutkan dengan analisis multivariat.

\section{Hasil}

Di antara 40 subjek didapatkan $27(67,5 \%)$ pasien dengan ESS. Pada Tabel 1 tertera jumlah subjek laki-laki dan jenis penyakit non bedah lebih banyak yang menderita ESS. Subjek dengan jenis penyakit non bedah memiliki jumlah ESS lebih banyak dibandingkan bedah. Sebagian besar subjek tidak mengalami malnutrisi. Kadar hormon tiroid pada subjek tertera pada Tabel 2

Pada Tabel 3 didapatkan jenis kelamin, usia, status nutrisi, jenis penyakit dan kejadian ESS bukan merupakan faktor risiko mortalitas pasien anak sakit kritis. Skor PELOD $\geq 20$, sepsis dan penggunaan inotropik merupakan faktor risiko mortalitas dengan OR (IK95\%) berturut-turut 29 (3,95-212,89); 12,67 $(1,40-114,42)$ dan 18,20 (2,89-114,60. Pada Tabel 4 ditunjukkan skor PELOD merupakan faktor risiko utama mortalitas dengan OR (IK95\%) 14,48 (1,10190,42) dengan $\mathrm{p}=0,04$. Pada Tabel 5 tertera bahwa nilai tengah kadar FT4 dan FT3 lebih rendah pada kelompok pasien yang meninggal. 
Ony Sapto Pramana dkk: Pengaruh ESS pada mortalitas anak sakit kritis

Tabel 1. Karakteristik dasar subjek penelitian

\begin{tabular}{|c|c|c|c|}
\hline \multirow[t]{2}{*}{ Variabel } & \multicolumn{2}{|c|}{ Tiroid } & \multirow[t]{2}{*}{$\mathrm{p}$} \\
\hline & ESS $(n=27)$ & Non ESS (n=13) & \\
\hline \multicolumn{4}{|l|}{ Jenis kelamin } \\
\hline Laki-laki & 15 & 6 & 0,577 \\
\hline Perempuan & 12 & 7 & \\
\hline \multicolumn{4}{|l|}{ Usia (bulan) } \\
\hline Median (min - max) & $32(3-192)$ & $24(1-156)$ & 0,773 \\
\hline \multicolumn{4}{|l|}{ Jenis penyakit } \\
\hline Bedah & 8 & 7 & 0,175 \\
\hline Non bedah & 19 & 6 & \\
\hline \multicolumn{4}{|l|}{ Status gizi } \\
\hline Malnutrisi & 10 & 3 & 0,377 \\
\hline Sehat & 17 & 10 & \\
\hline \multicolumn{4}{|l|}{ Skor PELOD } \\
\hline Median (min - max) & $10(1-33)$ & $12(1-22)$ & 0,415 \\
\hline \multicolumn{4}{|l|}{$\mathrm{TSH}(\mu \mathrm{IU} / \mathrm{ml})$} \\
\hline Median (Min - Max) & $1,59(0,11-14,23)$ & $1,05(0,39-14,23)$ & 0,773 \\
\hline \multicolumn{4}{|l|}{ FT4 (pmo/l) } \\
\hline Rerata $\pm S B$ & $12,63 \pm 4,44$ & $22,70 \pm 5,49$ & $<0,001$ \\
\hline \multicolumn{4}{|l|}{ FT3 $(\mathrm{pmo} / \mathrm{l})$} \\
\hline Median (Min - Max) & $1,73(0,76-2,70)$ & $4,08(3,36-6,32)$ & $<0,001$ \\
\hline
\end{tabular}

Tabel 2. Profil hormon tiroid pada subjek penelitian

\begin{tabular}{lccccc}
\hline Variabel & Rerata & SB & Median & Minimum & Maksimum \\
\hline TSH $(\mu \mathrm{IU} / \mathrm{ml})$ & 2,62 & 3,38 & 1,39 & 0,11 & 14,23 \\
FT4 $(\mathrm{pmol} / \mathrm{l})$ & 15,89 & 6,72 & 15,26 & 6,06 & 30,23 \\
FT3 $(\mathrm{pmo} / \mathrm{l})$ & 2,52 & 1,41 & 2,13 & 0,76 & 6,32 \\
\hline
\end{tabular}

\section{Pembahasan}

Berbagai perubahan fungsi tiroid akan ditemukan pada penyakit sistemik dengan tanpa adanya bukti kelainan kelenjar tiroid. Penelitian mendapatkan penurunan kadar T3, dikuti dengan penurunan T4, dan TSH. Perubahan hormon tiroid ini disebut dengan ESS. ${ }^{8}$ Kejadian ESS pada penelitian kami 67,5\%. Dari 40 subjek penelitian didapatkan 27 pasien mengalami ESS. Data di Amerika Serikat melaporkan kejadian ESS berkisar 40\%-100\%. ${ }^{9}$ Brinker dkk ${ }^{10}$ melaporkan hasil serupa, dari 69 pasien di PICU, 45(65\%) pasien mengalami ESS. Penelitian da Silva $\mathrm{dkk}^{11}$ pada neonatus dengan sepsis mendapatkan kejadian ESS $17(60,7 \%)$ neonatus dari 28 subjek. Penelitian lain pada pasien dewasa oleh Qari ${ }^{12}$ melaporkan kejadian ESS 86 (17\%) orang dari 520 pasien di ICU. Kejadian ESS yang bervariasi kemungkinan berkaitan dengan berbagai kondisi berbeda yang memengaruhi, misalnya perbedaan kejadian sepsis, berat ringan penyakit dasar, jenis penyakit, penggunaan obat yang memengaruhi fungsi tiroid, dan sebagainya.

Kami mendapatkan kejadian ESS pada 15 $(55,6 \%)$ anak laki-laki, $19(70,4 \%)$ anak dengan gizi baik, dan 17 (63\%) anak dengan jenis penyakit non bedah. Hal yang kurang lebih sama didapatkan oleh Bambang dkk ${ }^{6}$ pada penelitian kejadian ESS pasien sepsis, dari 30 pasien 20 (67\%) anak adalah laki-laki dengan gizi baik dan 23 (77\%) anak dengan jenis penyakit non bedah. Pada pasien dewasa, kejadian ESS juga lebih sering terjadi pada kelompok pasien non bedah. ${ }^{12}$ Kadar FT4 dan FT3 pada berbeda bermakna pada kelompok ESS dibandingkan non ESS. Penelitian oleh Kumar dkk ${ }^{13}$ pada 100 orang yang dirawat di ICU menunjukkan hal serupa, didapatkan perbedaan kadar FT3 dan FT4 
pada kelompok survivors dibanding non survivors, sedangkan kadar TSH tidak berbeda.

Jenis kelamin, usia, malnutrisi, jenis penyakit, dan ESS bukan merupakan faktor risiko mortalitas. Hasil ini serupa dengan yang dilaporkan oleh de
Araujo dkk, ${ }^{14}$ pada pasien anak yang di rawat di ruang intensif, bahwa jenis kelamin dan jenis penyakit bukan faktor risiko mortalitas. Malnutrisi dalam penelitian kami bukan merupakan faktor risiko mortalitas, berbeda dengan penelitian oleh Bechard $\mathrm{dkk}^{15}$ pada

Tabel 3. Analisis bivariat faktor-faktor risiko mortalitas

\begin{tabular}{|c|c|c|c|c|}
\hline \multirow[t]{2}{*}{ Variabel } & \multicolumn{2}{|c|}{ Luaran } & \multirow[t]{2}{*}{ OR (IK95\%) } & \multirow[t]{2}{*}{$\mathrm{p}$} \\
\hline & Meninggal $(n=9)$ & Hidup $(n=31)$ & & \\
\hline \multicolumn{5}{|l|}{ Jenis kelamin } \\
\hline Laki-laki & 4 & 17 & 0,66 & \multirow[t]{2}{*}{0,583} \\
\hline Perempuan & 5 & 14 & $(0,15-2,93)$ & \\
\hline \multicolumn{5}{|l|}{ Usia (tahun) } \\
\hline$<5$ & 7 & 13 & 2,53 & \multirow[t]{2}{*}{0,292} \\
\hline$\geq 5$ & 2 & 18 & $(0,45-14,20)$ & \\
\hline \multicolumn{5}{|l|}{ Skor PELOD } \\
\hline$\geq 20$ & 6 & 2 & 29 & \multirow[t]{2}{*}{0,001} \\
\hline$<20$ & 3 & 29 & $(3,95-212,89)$ & \\
\hline \multicolumn{5}{|l|}{ Status gizi } \\
\hline Malnutrisi & 5 & 8 & 3,59 & \multirow[t]{2}{*}{0,093} \\
\hline Sehat & 4 & 23 & $(0,77-16,79)$ & \\
\hline \multicolumn{5}{|l|}{ Jenis penyakit } \\
\hline Bedah & 1 & 14 & 0,15 & \multirow[t]{2}{*}{0,063} \\
\hline Non bedah & 8 & 17 & $(0,02-1,36)$ & \\
\hline \multicolumn{5}{|l|}{ Sepsis } \\
\hline $\mathrm{Ya}$ & 8 & 12 & 12,67 & \multirow[t]{2}{*}{0,008} \\
\hline Tidak & 1 & 19 & $(1,40-114,42)$ & \\
\hline \multicolumn{5}{|c|}{ Penggunaan inotropik } \\
\hline $\mathrm{Ya}$ & 7 & 5 & 18,20 & \multirow[t]{2}{*}{$<0,001$} \\
\hline Tidak & 2 & 26 & $(2,89-114,60)$ & \\
\hline \multicolumn{5}{|l|}{ Kategori tiroid } \\
\hline ESS & 8 & 19 & 5,05 & \multirow[t]{2}{*}{0,120} \\
\hline Non ESS & 1 & 12 & $(0,56-45,64)$ & \\
\hline
\end{tabular}

Tabel 4. Analisis multivariat faktor risiko mortalitas

\begin{tabular}{lcc}
\hline Variabel & $\mathrm{p}$ & OR (IK95\%) \\
\hline Skor PELOD $(\geq 20)$ & 0,042 & $14,48(1,10-190,42)$ \\
Sepsis (Ya) & 0,072 & $14,68(0,79-273,04)$ \\
Penggunaan inotropik (Ya) & 0,169 & $5,04(0,50-50,75)$ \\
\hline
\end{tabular}

Tabel 5. Hubungan kadar hormon tiroid dengan mortalitas

\begin{tabular}{lccc}
\hline Variabel & \multicolumn{3}{c}{ Komparasi } \\
\cline { 2 - 4 } & Meninggal $(\mathrm{n}=9)$ & $\operatorname{Hidup}(\mathrm{n}=31)$ & $\mathrm{p}$ \\
\hline TSH , median (min - max) & $1,40(0,21-3,12)$ & $1,38(0,11-14,23)$ & 0,662 \\
FT4, median (min - max) & $10,16(6,90-23,35)$ & $16,31(6,06-30,23)$ & 0,019 \\
FT3, median (min - max) & $1,13(0,76-4,16)$ & $2,49(0,89-6,32)$ & 0,002
\end{tabular}


1622 anak usia 1 bulan hingga 18 tahun, status gizi kurang merupakan faktor risiko mortalitas pada anak yang dirawat di PICU dengan ventilator mekanik. Skor PELOD $\geq 20$, sepsis, dan penggunaan inotropik merupakan faktor risiko mortalitas. Hasil studi oleh Metta $\mathrm{dkk}^{16}$ melaporkan perbedaan skor PELOD pada kelompok survivors dan non survivors pada anak yang dirawat di PICU dan skor PELOD $\geq 20$ berkaitan dengan survival rate yang rendah.

Sepsis berhubungan erat dengan mortalitas, tanpa penanganan yang tepat risiko mortalitas akan meningkat. Pada penelitian kami, risiko mortalitas pasien sepsis akan meningkat 12 kali. Duapuluh pasien mengalami sepsis dan 8 di antaranya meninggal. Hasil studi Wolfler ${ }^{17}$ pada anak yang dirawat di PICU menunjukkan bahwa anak dengan sepsis memiliki angka morbiditas dan mortalitas yang tinggi. Kondisi severe sepsis dan syok sepsis memiliki mortalitas berturut-turut $17,7 \%$ dan 50,8\%. Tanurahardja $\mathrm{dkk}^{7}$ melaporkan $14(46 \%)$ dari 30 anak yang mengalami sepsis di PICU meninggal dunia, sedangkan Kaur dkk ${ }^{18}$ melaporkan dari 50 anak yang dirawat di PICU, 28 (56\%) di antaranya meninggal.

Penggunaan inotropik pada penelitian kami berhubungan dengan peningkatan risiko mortalitas. Hal yang sama dikemukakan oleh Alshuheel $\mathrm{dkk}^{19}$ serta Volakli $\mathrm{dkk}^{20}$ yang melaporkan bahwa penggunaan inotropik merupakan faktor risiko mortalitas.' Hal tersebut kemungkinan berkaitan dengan derajat keparahan penyakit yang melibatkan disfungsi otot jantung. Pada penelitian kami yang melibatkan 27 anak dengan ESS, 8 di antaranya meninggal. Hasil ini bermakna secara klinis, tetapi tidak bermakna secara statistik. Menurut Tognisi $\mathrm{dkk}^{3}$ mortalitas pasien dengan ESS berhubungan dengan penyakit dasar, derajat keparahan dan durasi penyakit. Hasil analisis multivariat nenunjukkan skor PELOD $\geq 20$ merupakan faktor risiko utama pada mortalitas. Hal serupa dilaporkan oleh Tanurahardja $\mathrm{dkk}^{7}$ bahwa risiko meninggal pada pasien dengan skor PELOD $\geq 20$ adalah 15 kali lebih besar. Hal tersebut karena skor PELOD yang tinggi menggambarkan adanya berbagai disfungsi organ. Penelitian oleh Tanurahardja $\mathrm{dkk}^{7}$ pada anak sepsis dilaporkan tidak terdapat hubungan kadar TSH dengan skor PELOD. Hebbar $\mathrm{dkk}^{21}$ melaporkan bahwa skor PELOD tidak berhubungan dengan disfungsi neuroendokrin, insufisiensi adrenal, dan ESS.

Kadar FT4 dan FT3 lebih rendah dan berbeda bermakna pada kelompok yang meninggal. Pada penelitian dengan subjek dewasa di ICU oleh Kumar $\mathrm{dkk}^{13}$ didapatkan hal berbeda, kadar hormon pada kelompok yang meninggal dan hidup berbeda pada kadar FT3, sedangkan kadar FT4 dan TSH tidak berbeda. Penelitian oleh Bambang $\mathrm{dkk}^{6}$ pada pasien sepsis di PICU dilaporkan tidak terdapat hubungan antara kadar TSH, FT4, dan FT3 dengan luaran pasien. Perbedaan hasil penelitian kemungkinan disebabkan perbedaan karakter subjek penelitian. Keterbatasan penelitian kami adalah pemeriksaan hormon tiroid dilakukan satu kali saja pada 24 jam pertama pasien dirawat sehingga kemungkinan belum terjadi perubahan kadar hormon tiroid yang bermakna.

\section{Kesimpulan}

Didapatkan bahwa euthyroid sick syndrome tidak berpengaruh pada mortalitas anak sakit kritis.

\section{Daftar pustaka}

1. Mebis, L \& Van den Berghe, G. The hypothalamus-pituitarythyroid axis in crtical illness. Neth J Med 2009;67:332-40.

2. De Groot, LJ. Non thyroidal illness syndrome: a form of hypothyroidsm. Dalam: Jamenson, JL, De Groot, LJ, penyunting. Endocrinology adult and pediatric. Edisi 6 . Philadelphia: Elsevier Inc; 2010.

3. Tognini S, Marchini F, Dardano, A. Non-thyroidal illness syndrome and short-term survival in a hospitalised older population. Age and Ageing 2010;39:46-50.

4. Plikat, K., Langgartner, J., Buettner, R. Frequency and outcome of patients with nonthyroidal illness syndrome in a medical intensive care unit. Metabolism: Clin Expp 2007;56:239-44.

5. Suvarna JC, Fande CN. Serum thyroid hormone profile in critically ill children. Indian J Pediatr 2009;76:1217-21.

6. Bambang, Purwanti A, dan Supriatna M. Hormon tiroid pada kondisi anak dengan sepsis. Pediatrica Indones 2014;54:24550.

7. Tanurahardja AG, Pudjiadi AH, Dwipoerwantoro PG, Pulungan A.. Thyroid hormon profile and PELOD score in children with sepsis. Paediatrica Indones 2014;54:245-50.

8. Angelousi AG, Karageorgopoulos DE, Kapaskeli AN, dan Falagas ME. Association between thyroid function tests at baseline and the outcome of patients with sepsis or septic shock: a systematic review. Eur J Endocrinol 2011;164:14755. 
9. Serhat A. Euthyroid sick syndrome. Diunduh 5 Januari 2016. Didapat dari: http://emedicine.medscape.com/ article/118651.

10. Brinker Md, Joosten KFM, Visser TJ, Wim CJ, Hop Rijke YBd, Hazelzet JA, dkk. Euthyroid sick syndrome in meningococcal sepsis: the impact of peripheral thyroid hormone metabolism and binding proteins. J Clin Endocrinol Metab 2005;90:406-9.

11. da Silva MHBN, de Araujo MCK, de Albuquerque Diniz EM, Ceccon MEJR, Werther Brunow, de Carvalho WB. Nonthyroidal illnesses syndrome in full-term newborns with sepsis. Arch Endocrinol Metab 2015;59: 528-3

12. Qari FA. Thyroid function status and its impact on clinical outcome in patients admitted to critical care. Pak J Med Sci 2015;31:915-9.

13. Kumar KVSH, Kapoor U, Kalia R, Chandra NSA, Singh P, dan Nangia R, dkk. Low triiodothyronine predicts mortality in critically ill patients. Indian J Endocrinol Metabolism 2013;17:285-8.

14. de Araujo Costa G, I Artur FI, Delgado Ferraro AI, OkayII ITS. Application of the pediatric risk of mortality score (PRISM) score and determination of mortality risk factors in a tertiary pediatric intensive care unit. CLINICS 2010;65:108792.

15. Bechard L, Duggan C, Decker RT. The association between nutritional status and mortality in critically ill children admitted to the pediatric intensive care unit. The FASEB J 2014;28 Supplement 1024.11.

16. Metta D, Soebardja D, Hudaya SD. The use of pediatric logistic organ dysfunction (PELOD) scoring system to determine the prognosis of patients in pediatric intensive care units. Pediatrica Indones 2006;46:1-6.

17. Wolfler A, Silvani P, Musicco M, Antonelli, M, da Salvo. Incidence of and mortality due to sepsis, severe sepsis and septic shock in Italian Pediatric Intensive Care Units: a prospective national survey. Pediatric Original 2008;34:1690-7.

18. Kaur G,Vinayak N, Mittal K, Kaushik JS and Aamir M. Clinical outcome and predictors of mortality in children with sepsis, severe sepsis, and septic shock. A prospective observational study. Indian J Crit Care Med 2014;18:437-41

19. Alsuheel AM dan Shati AA. Factors Predicting Mortality in Pediatric Intensive Care Unit in a Tertiary Care Center Southwest Region. Saudi Arabia J Med Sci 2014;5:113-20.

20. Volakli E, Sdougka M, Tamiolaki M, Tsonidis C, Reizoglou $\mathrm{M}$ and Giala M.. Demographic profile and outcome analysis of pediatric intensive care patients. Hippokratia 2011;15:316-22

21. Hebbar K, Rigby MR, Felner EI, Easley KA, Fortenberry JD. Neuroendocrine dysfunction in pediatric critical illness. Pediatric Critical Care Medicine : a Journal of the Society of Critical Care Medicine and the World Federation of Pediatric Intensive and Critical Care Societies 2009;10:35-40. 